Микола Миколайович Биченок (доктор техн. наук, с.н.с.)

Олександр Володимирович Войтко (канд. військ. наук)

Володимир Миколайович Чернега (канд. техн. наук)

Національний університет оборони Украӥни імені Івана Черняховського, Київ, Украӥна

\title{
ПІДХІД ЩОДО ОЦІНЮВАННЯ РИЗИКІВ ЖИТТєДІЯЛЬНОСТІ
}

Сучасний стан техногенної та природної безпеки України характеризується небезпечними для життєдіяльності змінами навколишнього середовища, які зумовлені, перш за все військовим конфліктом на території Донецької $і$ Луганської областей, які характеризуються значною кількістю підприємств важкої та гірничодобувної промисловості, а також впливом глобальних змін клімату, нераціональним природокористуванням, суцільною зарегульованістю річкової мережі, закриттям численних нерентабельних шахт і кар'єрів методом повного або часткового затоплення та інше. За таких умов постійно зростають ризики природно-техногенних аварій $i$ катастроф, а також людські та матеріальні втрати від них і непродуктивні витрати на локалізацію та ліквідацію негативних наслідків. Тому особливої актуальності набуває проблема забезпечення безпеки життєдіяльності населення 8 умовах можливих чи реальних надзвичайних ситуацій. В даній роботі пропонуються адекватні методи оцінювання ризиків життєдіяльності з метою їх мінімізаџії та ліквідації.

Ключові слова: надзвичайні ситуаџї; індивідуальний ризик життєдіяльності; колективний ризик життєдіяльності; інтегральний ризик життєдіяльності.

\section{Вступ}

Пріоритетним національним інтересом в Україні, як і в усіх цивілізованих країнах, $\epsilon$ забезпечення безпеки життєдіяльності людини, суспільства i держави в умовах потенційних i реальних надзвичайних ситуацій (НС) техногенного та природного характеру. Це неможливо без детального аналізу існуючого стану техногенної та природної безпеки в Україні, його моніторингу у довгостроковій динаміці та розроблюванні заходів 3 оцінювання та зі зменшення ризиків виникнення НС. В цілому загальний стан техногенної та природної безпеки в Україні є складним [1].

Військовий конфлікт на Сході України, а саме на території розвинутих гірничодобувних районів Донецької і Луганської областей, значно загострив існуючі екологічні проблеми, які мали місце і до 2014 року. Донецький регіон займав провідні місця за економічними показниками серед інших регіонів України, але розвиток промисловості відбувався без урахування екологічного чинника. Наявність значної кількості підприємств важкої промисловості та добувних галузей призвели до значного дисбалансу в структурі екосистем [1,2-4].

Зона бойових дій завжди стає зоною екологічного лиха що пов'язане 3 аномальним забрудненням атмосферного повітря, земельних, водних і біотичних ресурсів. Так, у результаті бойових дій, було пошкоджено чи зруйновано численні гірничодобувні, коксохімічні та енергетичні підприємства, що призвело до зростання ризиків виникнення надзвичайних ситуацій на об'єктах критичної інфраструктури 3 масштабними негативними наслідками для населення i довкілля $[1,5]$. Ці території характеризуються великою кількістю хімічно небезпечних об'єктів (ХНО) - надмірною концентрацією підприємств важкої індустрії зі значно зношеними основними фондами. Загальна кількість ХНО в Україні станом на 2017 рік складає 931 об'єкт [1]. Суттєву небезпеку становлять металургійні підприємства, агломераційні фабрики, хімічні та гірничодобувні підприємства. Так, на території Донецької i Луганської областей знаходиться близько 40 великих i середніх хімічних підприємств, які виготовляють понад 25\% хімічної продукції від іiі загального обсягу виробництва в Україні. До цього додається щільна транспортна інфраструктура (магістральні трубопроводи, залізниці, автошляхи), що активно використовувались для транспортування небезпечних хімічних речовин (HXP) [6].

Отже, в Україні впродовж останнього часу має місце порушення рівноважного екологічного стану верхньої зони порід, а також меж річкових басейнів i надр. Це призвело до активізації небезпечних екзогенних геологічних процесів (зсувних, карстових, підтоплень, просідань тощо) та ускладненню умов експлуатації житлових і промислових комплексів. Тому більшість існуючих природно-техногенних систем можна розглядати як джерела підвищеної небезпеки, що пов'язані $з$ порушенням проектних умов їхньої експлуатації. Відповідно зростають ризики природно-техногенних аварій і катастроф, а також людські й матеріальні втрати від них і непродуктивні витрати на ліквідацію негативних наслідків. За експертними оцінками, техногенний індивідуальний ризик в Україні на декілька порядків перевищує значення максимально 
припустимого техногенного ризику у країнах ЄС.

Постановка проблеми. Подальший екологоекономічний розвиток України потребує особливої уваги до захисту населення та об'єктів життєдіяльності від можливих і реальних НС, які спричиняються активізацією господарської діяльності у природно-техногенному середовищі. Урядом прийнято постанову [7] щодо деяких питань запобігання виникненню надзвичайних ситуацій природного та техногенного характеру. Рішення прийняте для зменшення ризику виникнення зазначених надзвичайних ситуацій в умовах встановлення особливого правового режиму на територіях України, тимчасово окупованих внаслідок збройної агресії Російської Федерації, та дії особливого періоду. Постановою, зокрема, передбачається:

низка заходів для убезпечення злагоджених дій єдиної державної системи цивільного захисту щодо прогнозування критичних ситуацій, усунення факторів, що сприяють їх виникненню в галузях та сферах суспільного життя, порушення функціонування яких може завдати шкоди життєво важливим національним інтересам України;

окреслюється коло галузей, сфер суспільного життя та об'єктів, порушення функціонування яких може завдати шкоди життєво важливим національним інтересам України;

розроблення та затвердження спеціальних заходів на випадок виникнення надзвичайних ситуацій техногенного та природного характеру, що призводять до припинення централізованого водопостачання, підприємствами, установами, організаціями, які провадять діяльність та надають послуги у сферах централізованого водопостачання та водовідведення, спільно 3 органами місцевого самоврядування.

Таким чином, підвищення ефективності заходів iз запобігання й мінімізації негативних наслідків НC вимагає завчасного виявлення та оцінки ризиків життєдіяльності на територіях підвищеної природно-техногенної небезпеки. Отже, потрібен інструментарій, що дозволить практично оцінювати ризики цих загроз.

Аналіз остатніх досліджень і публікацій. Аналіз існуючих методологічних підходів щодо вирішення проблеми оцінки ризиків небезпеки техногенного та природного походження показав, що цією проблематикою займаються багато вітчизняних вчених $[8-12,14]$. Але на даний час не існує однозначного науково-методичного апарату щодо оцінки ризиків життєдіяльності населення. Запропонована методика прогнозування наслідків виливу (викиду) небезпечних хімічних речовин при аваріях на промислових об'єктах і транспорті [13] потребує удосконалення та приведення у відповідність до вимог нормативно-правових актів та умов сучасності.
В існуючих методиках оцінка ризику $\mathrm{R}$ для населення N від НС природного і техногенного характеру [8-9] визначається як математичне очікування людських втрат $\mathrm{M}[\mathrm{N}]$ у межах певної території (області, адміністративного району, міста, іншого населеного пункту) за формулою:

$\mathrm{R}=\mathrm{M}[\mathrm{N}]=\mathrm{P} \iint_{\mathrm{Sr}} \int_{\Phi \min }^{\Phi} \mathrm{P}(\Phi) \Psi(\mathrm{x}, \mathrm{y}) \mathrm{f}(\mathrm{x}, \mathrm{y}, \Phi) \mathrm{d} \Phi \mathrm{d} x d \mathrm{y},(1)$

де $\mathrm{P}$ - ймовірність природної або техногенної НС; $\Phi$ - інтенсивність впливу вражаючого фактору HC; $\Phi_{\min }, \Phi_{\max }$ - мінімально і максимально можлива інтенсивність впливу вражаючого фактору; $\mathrm{Sr}$ - область інтегрування (зона ураження), тобто територія, на яку поширюється

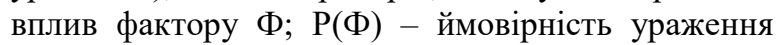
людей залежно від інтенсивності фактору $\Phi$ (функція “вплив - ефект”); Ч(х,y) - щільність населення в межах зони ураження; $\mathrm{f}(\mathrm{x}, \mathrm{y}, \Phi)-$ щільність розподілу інтенсивності фактора $\Phi$ по ураженій зоні з координатами (х,у).

Для оцінки більш складних ситуацій, що спостерігаються в реальному житті, формули розрахунку ризику ускладнюються. Наприклад, у [8] пропонується розраховувати річний ризик $\mathrm{R}(\mathrm{t})$ як суму всіх імовірних наслідків НС:

$$
\mathrm{R}(\mathrm{t})=\mathrm{y}_{\mathrm{M}}(\mathrm{t})+\mathrm{Y}_{\text {л }}(\mathrm{t}) \text {, }
$$

де $\mathrm{y}_{\mathrm{M}}$ - сумарні річні майнові втрати (в економічному еквіваленті); У здоров'я населення, включаючи смертельні випадки (в економічному еквіваленті); $\mathrm{t}$ - час, протягом якого оцінюється ризик (у роках), причому:

$$
\begin{aligned}
& \mathrm{y}_{\mathrm{M}}(\mathrm{t})=\sum_{\mathrm{i}=1, j=1}^{\mathrm{n}, \mathrm{m}} \mathrm{M}_{\mathrm{ij}}(\mathrm{t}) \mathrm{Y}_{\mathrm{ij}}(\mathrm{t}), \\
& \mathrm{y}_{\text {л }}(\mathrm{t})=\sum_{\mathrm{i}=1, \mathrm{j}=1}^{\mathrm{n}, \mathrm{m}} \mathrm{R}_{\mathrm{ij}}(\mathrm{t}) \mathrm{X}_{\mathrm{ij}}(\mathrm{t}),
\end{aligned}
$$

де $\mathrm{M}_{\mathrm{ij}}(\mathrm{t})$ - частота виникнення j-тої майнової шкоди від і-того вражаючого фактору; $\mathrm{Y}_{\mathrm{ij}}(\mathrm{t})$ обсяг (ринкова вартість) майнової шкоди; $\mathrm{R}_{\mathrm{ij}}(\mathrm{t})$ частота виникнення j-того типу ураження людей від і-того вражаючого фактору; $\mathrm{X}_{\mathrm{ij}}(\mathrm{t})$ - вартість втрат, зумовлених ј-тим типом ураження людей від і-того вражаючого фактору.

Метою статті $\epsilon$ визначення підходів для практичного оцінювання ризиків життєдіяльності в Україні.

\section{Виклад основного матеріалу дослідження.}

Зазначені методичні підходи можуть бути реалізовані лише частково внаслідок: по-перше, неможливості зафіксувати всі без винятку види втрат від НС (як матеріальних, так і для здоров'я); по-друге, неможливості адекватно оцінити в грошовому еквіваленті різнорідні види соціальних i медичних втрат [3, 4]. Водночас найбільш 
соціально значимі види втрат, такі як смертельні випадки, травми й отруєння, втрата житла та/або майна населенням внаслідок НC, можуть бути достатньо надійно зафіксовані й оцінені.

Базовим поняттям, що характеризує рівень небезпеки НC, є індивідуальний ризик RI, тобто ймовірність (частота) ураження окремого індивіда внаслідок випадкової реалізації небезпечної події, що впливатиме певним вражаючим фактором. Якщо існує достатня статистика виникнення цієї події, то оцінка індивідуального ризику від впливу iii вражаючого фактору визначається формулою:

$$
\mathrm{RI}=\mathrm{n} / \mathrm{N} \text {, }
$$

де $\mathrm{n}$ - кількість людських втрат із цієї причини; $\mathrm{N}$ - кількість населення в межах оцінюваної території.

Інтегральною кількісною мірою небезпеки НС $\epsilon$ колективний ризик $\mathrm{RN}$, пов'язаний 3 індивідуальним ризиком формулою:

$$
\mathrm{RN}=\mathrm{RI} \cdot \mathrm{N},
$$

де $N$ - загальна кількість людей, які можуть потрапити в зону ураження.

Регіональний ризик визначається так само, однак усереднено для всього населення регіону, який включає потенційну зону ураження.

Надзвичайні ситуації природно-техногенного характеру зазвичай охоплюють значні території в межах кількох адміністративних одиниць. Тому для таких НC зникають відмінності між колективним i регіональним ризиком. Причому зони можливого прояву (реалізації) таких природних (з техногенною складовою активізації) небезпек (руйнівних землетрусів, карсту, підтоплення, зсувів тощо) стають потенційно небезпечними територіями (ПНТ). Натомість ризик під час техногенних НC на потенційно небезпечних об'єктах (ПНО), наприклад, 3 викидом токсичних речовин, переважно визначається потениійним територіальним техногенним ризиком і імовірністю знаходження в зоні ймовірного впливу вражаючого фактору за тим чи іншим експертним сценарієм розвитку НС. Звідси виникає потреба оцінки ризиків на регіональному та об'єктовому рівнях.

Оскільки головною складовою регіонального рівня ризику НС є природні небезпеки, то за основу для регіональних оцінок можна використати формулу ризику життєдіяльності від природних небезпек [9]:

$$
\mathrm{R}_{\mathrm{is}}(\mathrm{F})=\sum_{\mathrm{i}}\left(\left(\mathrm{S}_{\mathrm{i}} / \mathrm{T}_{\mathrm{i}}\right) \mathrm{r}_{\mathrm{si}} \mathrm{Vt}_{\mathrm{i}} \mathrm{Vs}_{\mathrm{i}}(1 / \mathrm{Ns})\right),
$$

де $\mathrm{S}_{\mathrm{i}}$ - площа (зона), що зазнала ураження i-тим вражаючим фактором $\mathrm{F}_{\mathrm{i}} ; \mathrm{T}_{\mathrm{i}}$ - час, протягом якого відбувалося ураження фактором $\mathrm{F}_{\mathrm{i}} ; \mathrm{r}_{\mathrm{si}}=\mathrm{Ns}_{\mathrm{i}} / \mathrm{S}_{\mathrm{i}}$ щільність населення зони ураження $\mathrm{S}_{\mathrm{i}} ; \mathrm{Ns}_{\mathrm{i}}$ кількість населення зони ураження; $\mathrm{Vt}_{\mathrm{i}}$ уразливість населення в часі; $\mathrm{Vs}_{\mathrm{i}}$ - уразливість населення по території; Ns - кількість населення регіону, щодо якого розраховується ризик.
На об’єктовому рівні для оцінки ризику НС можна скористатися формулою техногенного ризику $\mathrm{R}_{\text {is }}(\mathrm{x}, \mathrm{y})$ [10-12]:

$$
\mathrm{R}_{\mathrm{i}}(\mathrm{x}, \mathrm{y})=\sum_{\mathrm{ij}} \mathrm{P}(\mathrm{A})_{\mathrm{i}} \mathrm{P}_{\mathrm{ij}}(\mathrm{x}, \mathrm{y}) \mathrm{P}(\mathrm{L})_{\mathrm{j}},
$$

де $\mathrm{P}(\mathrm{A})_{\mathrm{i}}$ - ймовірність аварії $A$ за сценарієм $i$; $\mathrm{P}_{\mathrm{ij}}(\mathrm{x}, \mathrm{y})$ - ймовірність досягнення порогової інтенсивності впливу вражаючого фактору (концентрації токсиканта) j в точці (х,y) для i-того сценарію; $\mathrm{P}(\mathrm{L})_{\mathrm{j}}$ - ймовірність смерті (або захворювання) людей L при досягненні порогової концентрації вражаючого фактору j.

Таким чином, оцінювання ризиків життєдіяльності (імовірності втрати здоров'я чи загибелі людей) в загальному випадку базується на наступних співвідношеннях.

Індивідуальні ризики життєдіяльності за видами загроз:

$$
\mathrm{R}_{\mathrm{is}}\left(\mathrm{w}_{\mathrm{j}}\right)=\mathrm{P}_{\mathrm{s}}\left(\mathrm{w}_{\mathrm{j}}\right) \mathrm{V}_{\mathrm{sf}}\left(\mathrm{w}_{\mathrm{j}}\right) \mathrm{V}_{\mathrm{nt}}\left(\mathrm{w}_{\mathrm{j}}\right) \mathrm{N}_{\mathrm{ns}}\left(\mathrm{w}_{\mathrm{j}}\right),
$$

де $\mathrm{R}_{\mathrm{is}}\left(\mathrm{W}_{\mathrm{j}}\right)$ - індивідуальний ризик загибелі на території $S$ від ј-того типу вражаючих впливів W (1/рік); $\mathrm{P}_{\mathrm{S}}\left(\mathrm{W}_{\mathrm{j}}\right)$ - небезпека (ймовірність) прояву на території $S$ вражаючих впливів $\mathrm{W}_{\mathrm{j}}$ (випадків/рік); $\mathrm{V}_{\mathrm{sf}}\left(\mathrm{W}_{\mathrm{j}}\right)$ - фізична уразливість території S від вражаючих впливів, що визначається співвідношенням площі ураженої частини території до іiі загальної площі $\mathrm{S}$ (частки одиниці); $\mathrm{V}_{\mathrm{nt}}\left(\mathrm{W}_{\mathrm{j}}\right)$ - часова уразливість населення, що визначається ймовірністю опинитися на території $\mathrm{S}$ під час прояву вражаючих впливів $\mathrm{W}_{\mathrm{j}}$ (частки одиниці); $\mathrm{V}_{\mathrm{ns}}\left(\mathrm{W}_{\mathrm{j}}\right)$ - просторова уразливість населення, що визначається ймовірністю потрапити на уражену частину території $\mathrm{S}\left(\mathrm{W}_{\mathrm{j}}\right)$ (частки одиниці).

Колективні ризики життєдіяльності за видами загроз:

$$
R_{n s}\left(W_{j}\right)=R_{\text {is }}\left(W_{j}\right) N_{\text {swj }} \text {, }
$$

де $\mathrm{R}_{\mathrm{ns}}\left(\mathrm{W}_{\mathrm{j}}\right)$ - колективний ризик загибелі чи втрати здоров'я на території $\mathrm{S}$ від вражаючих впливів (чол./piк); $\mathrm{N}_{\mathrm{swj}}$ - загальна кількість населення у межах території S (чол.).

Інтегральний ризик життєдіяльності:

$$
\mathrm{R}_{\mathrm{ns}}(\mathrm{W})=\sum_{\mathrm{j}} \mathrm{k}_{\mathrm{j}} \mathrm{R}_{\mathrm{ns}}\left(\mathrm{W}_{\mathrm{j}}\right),
$$

де $\mathrm{R}_{\mathrm{ns}}(\mathrm{W})$ - колективний ризик загибелі чи втрати здоров'я на території $\mathrm{S}$ від вражаючих впливів $\mathrm{W}$ (чол./piк); $\mathrm{k}_{\mathrm{j}}$ - нормуючий ваговий коефіцієнт для кожного ј-того типу вражаючих впливів $\mathrm{W}_{\mathrm{j}}$ (частки одиниці).

Інтегральний індивідуальний територіальний ризик життєдіяльності:

$$
\mathrm{R}_{\mathrm{s}}(\mathrm{W})=\mathrm{R}_{\mathrm{ns}}(\mathrm{W}) / \mathrm{N}_{\mathrm{s}},
$$


де $\mathrm{N}_{\mathrm{s}}$ - загальна кількість населення у межах території S (чол.).

Оцінювання ризиків життсдіяльності на конкретному прикладі.

Під ризиком життєдіяльності від можливої аварії на хімічно небезпечному об'єкті (ХНО) розуміється ймовірність загибелі або захворювання людей внаслідок отруєння у випадку їхнього перебування в прогнозованій зоні хімічного зараження (ЗХ3). Оцінювання ризиків життєдіяльності від можливих хімічно небезпечних аварій базується на результатах моделювання наслідків аварійного викиду небезпечних хімічних речовин (НХР), що здійснюється 3 урахуванням обсягів викиду, метеорологічних умов і відповідних геометричних параметрів 3Х3. За результатами пооб'єктного моделювання визначаються ризики життєдіяльності на регіональному рівні.

На основі розробленого вище методу формулюється алгоритм комплексного оцінювання ризиків життєдіяльності в умовах можливих аварій на ХНО.

Практичне відпрацювання алгоритму здійснено на конкретних прикладах можливих хімічно небезпечних аварій 3 урахуванням небезпеки прояву процесів підтоплення та просідання.

Для найбільш небезпечних ХНО Запорізької області змодельовані зони хімічного ураження в умовах можливих аварій з максимальним обсягом викиду токсичних речовин 3 урахуванням актуальних середньо-кліматичних значень метеорологічних параметрів.

Запропонований метод комплексного оцінювання ризиків життєдіяльності розглядається далі на методичному прикладі можливої аварії на Мелітопольському ДКП “Водоканал”. Для моделювання використано такі вхідні параметри: вид НХР - хлор; осяг викиду - 300 т; температура повітря - $+20^{0} \mathrm{C}$; напрямок вітру - північний; швидкість вітру - 3 м/с; ступінь вертикальної стійкості повітря - ізотермія; фактори впливу природної небезпеки на ХНО - підтоплення і просідання лесових грунтів.

Відповідно до методики $[13,14]$ визначаються наступні параметри можливої 3Х3:

- кут сектора 3Х3 з урахуванням стійкості напрямку вітрового потоку i швидкості вітру $\alpha=45^{0}$;

-глибина зони хімічного зараження $\mathrm{R}=26,8$ км;

-можлива площа $3 \mathrm{X} 3$

$\mathrm{S}=\pi \mathrm{R}^{2} \cdot 45^{\circ} / 360^{\circ}=281,8$ км$^{2}$

-чисельність населення в 3Х3 N = 18722 чол.;

-площа максимально можливого поширення токсичної хмари $\mathrm{S}_{\max }=\pi \mathrm{R}^{2}=2255$ км$^{2}$.

Як уже зазначалося, оцінювання техногенного ризику життєдіяльності в умовах можливих аварій на ХНО здійснюється за формулою:

$$
\mathrm{R}_{2}\left(\mathrm{H}_{2}\right)=\mathrm{P}_{2}\left(\mathrm{H}_{2}\right) \mathrm{V}_{2}\left(\mathrm{H}_{2}\right) \mathrm{K}_{2}\left(\mathrm{H}_{2}\right) \mathrm{N},
$$

де $\mathrm{R}_{2}\left(\mathrm{H}_{2}\right)$ - колективний ризик втрати здоров'я чи загибелі населення на даній території при можливій аварії на XНО з викидом НХР (чол/рік); $\mathrm{P}_{2}\left(\mathrm{H}_{2}\right)$ - ймовірність виникнення аварії на ХНО (випадків/рік); $\mathrm{V}_{2}\left(\mathrm{H}_{2}\right)$ - уразливість території від можливої аварії на ХНО (частки одиниці); $\mathrm{K}_{2}\left(\mathrm{H}_{2}\right)$ - просторова уразливість населення (частки одиниці); $\mathrm{N}$ - чисельність населення на території дослідження (чол.).

Імовірність виникнення аварії на ХНО 3 викидом токсичних речовин визначається як середньорічна частота хімічно небезпечних аварій у заданому регіоні, від яких можуть постраждати (захворіти або загинути) люди внаслідок отруєння. Наприклад, за даними ДСНС України у 2006 році зареєстровано 4 аварії на ХНО 3 викидом НХР, унаслідок яких постраждало 6 чоловік [15]. На той час загальна кількість ХНО в Україні складала 1575 об'єктів.

Таким чином, статистична ймовірність аварії $\mathrm{P}_{2}\left(\mathrm{H}_{2}\right)$ на XНО 3 викидом НХР, яка становить загрозу для життєдіяльності населення, визначається за співвідношенням

$$
\mathrm{P}_{2}\left(\mathrm{H}_{2}\right)=4 / 1575=2,5 \cdot 10^{-3} \text {. }
$$

Уразливість території $\mathrm{V}_{2}\left(\mathrm{H}_{2}\right)$ від можливої аварії на ХНО визначається відношенням ураженої частини території Запорізької області до пї загальної площі

$$
\mathrm{V}_{2}\left(\mathrm{H}_{2}\right)=281,8 / 27200=0,01236 .
$$

Просторова уразливість населення регіону $\mathrm{K}_{2}\left(\mathrm{H}_{2}\right)$ в умовах можливої аварії на ХНО визначається співвідношенням кількості населення в зонах можливого ураження до загальної кількості населення Запорізької області

$$
\mathrm{K}_{2}\left(\mathrm{H}_{2}\right)=1781 / 1929200=0,0372 .
$$

Таким чином, індивідуальний техногенний ризик життєдіяльності в регіоні при повномасштабному прояві можливої аварії становитиме

$$
\begin{aligned}
& \mathrm{R}_{2}\left(\mathrm{H}_{2}\right)=\mathrm{P}_{2}\left(\mathrm{H}_{2}\right) \mathrm{V}_{2}\left(\mathrm{H}_{2}\right) \mathrm{K}_{2}\left(\mathrm{H}_{2}\right)=2,5 \cdot 10^{-3} . \\
& 0,01036 \cdot 0,0372=9,63 \cdot 10^{-7} \text { чол / рік. }
\end{aligned}
$$

\section{Висновки й перспективи подальших досліджень}

Для більш обгрунтованого оцінювання ризиків життєдіяльності від продовження експлуатації ХНО на території України необхідні подальші дослідження у таких напрямах:

аналіз впливу випереджаючого старіння i зношення технологічного устаткування ХНО порівняно 3 його заміною та реконструкцією в контексті ризиків життєдіяльності;

розробка вагових коефіцієнтів впливу технологічних, геологічних та інших чинників на формування ризиків життєдіяльності;

удосконалення систем об'єктового і регіонального моніторингу ХНО 3 урахуванням взаємозв'язків i взаємовпливів техногенних i природних чинників;

розробка показників і відпрацювання критеріїв 
оцінки динаміки змін в часі техногенних $\mathrm{i}$ природних складових інтегрального ризику

\section{Лimepamypa}

1. Аналітичний огляд стану техногенної та природної безпеки в Україні за 2017 рік. URL: http://www.dsns.gov.ua/files/2017/8/18/Analit\%20dopovid/ analit\%20oglad.pdf. (дата звернення: 15.12.2018). 2. Дубель В. М. Особливості еколого-економічного розвитку регіонів України. Вісник Донецького начіонального університету. Серія В. Економіка і право. 2014. №1. C.52-56. URL: http://jvestnikc.donnu.edu.ua/article/view/382 (дата звернення: 15.12.2018). 3. Биченок М. М., Рогожин О.Г. До інтегральної оцінки соціальних ризиків виникнення надзвичайних ситуацій. Екологія $і$ ресурси. К.: ІПНБ, 2003. № 6. С.108-124. 4. Биченок М. М., Рогожин О. Г., Яковлєв Є. О. Про оцінювання ризиків життєдіяльності і господарювання у природно-техногенній сфері. Екологія $i$ ресурси. К.: ІПНБ, 2004. № 10. С.64-73. 5. Арсен Аваков Стратегія відновлення цілісності України і деокупації Донбасу. "Механізм малих кроків". URL: http://mvs.gov.ua/ua/pages/plan deokupacii donbasu meha nizm malih krokiv.htm. (Дата звернення 15.12.2018). 6. Побережна Л. Я., Станецький А. I. Оцінка потенційних екологічних ризиків внаслідок проведення антитерористичної операції. Науково-технічний журнал “Техногенно-екологічна безпека". 2017. № 2. С. 45-52. 7. Деякі питання запобігання виникненню надзвичайних ситуацій природного та техногенного характеру. Постанова КМУ від 26 вересня 2018 року №779. URL: https://www.kmu.gov.ua/ua/npas/deyakipitannya-zapobigannya-vinik. (дата звернення: 15.12.2018). 8. Алымов В. Т., Тарасова Н. П. Техногенный риск: Анализ и оценка. Учебное пособие життєдіяльності від загроз негативного впливу $\mathrm{XHO}$. для ВУЗов. М.: ИКЦ "Академкнига", 2004. 188 с. 9. Рагозин А. Л. Основные модели и методы оценки природных рисков. Оценка и управление природными рисками. Тематический том. М.: Издательская фирма "КРУК", 2003. С.131-142. 10. Іванюта С. П. ГІС реалізація оцінки ризику життєдіяльності від аварій на хімічно небезпечних об'єктах. Екологія $і$ ресурси. К.: ІПНБ, 2005. № 11. С.95-101. 11. Іванюта С. П. Розробка методики оцінки ризику збитків від надзвичайних ситуацій в регіонах України. Восточно-Европейский журнал передовых технологий. Экология. 2015. №3/6 (75). С.48-53. 12. Яцюк О. П. Прогнозування наслідків виливу (викиду) небезпечних хімічних речовин у разі аварій на хімічно небезпечних об'єктах. URL: http://nd.nubip.edu.ua/2015 8/12.pdf. (дата звернення: 15.12.2018). 13. Про затвердження Методики прогнозування наслідків виливу (викиду) небезпечних хімічних речовин при аваріях на промислових об'єктах і транспорті. Наказ Міністерства 3 питань надзвичайних ситуацій та у справах захисту населення від наслідків Чорнобильської катастрофи, Міністерства аграрної політики, Міністерства економіки, Міністерства екології і природних ресурсів №73/82/64/122 від 27.03.2001. URL: http://zakon.rada.gov.ua/laws/show/z0326-01. (дата звернення: 15.12.2018). 14. Беспалов В. П. Порівняння методик МО і МНС для прогнозування наслідків аварії 3 хімічно небезпечною речовиною. Системи підтримки прийняття рішень. Теорія і практика. 2008. №6. С6064. 15. Національна доповідь про стан техногенної та природної безпеки в Україні у 2006 р. К.: ДП “Чорнобильінтерінформ”, 2007. 236 с.

\title{
ПОДХОД К ОЦЕНИВАНИЮ РИСКОВ ЖИЗНЕДЕЯТЕЛЬНОСТИ
}

\author{
Николай Николаевич Быченок (доктор техн. наук, с.н.с.) \\ Александр Владимирович Войтко (канд. воен. наук) \\ Владимир Николаевич Чернега (канд. техн. наук)
}

\section{Национальный университет оборонь Украины имени Ивана Черняховского, Киев, Украина}

Современное состояние техногенной и природной безопасности Украины характеризуется опасными для жизнедеятельности изменениями окружающей среди, которые вызваны прежде всего военным конфликтом на территории Донецкой и Луганской областей, которые характеризуются значительным количеством предприятий тяжелой и горнодобывающей промышленности, а также влиянием глобальных изменений климата, нерачиональным природопользованием, зарегулированностью речной сети, закрытием многочисленных нерентабельных шахт методом полного или частичного затопления и другое. В этих условиях постоянно возрастают риски природно-техногенных аварий и катастроф, а также человеческие и материальные потери от них и непроизводительные затраты на локализачию и ликвидацию негативных последствий. Поэтому особую актуальность приобретает проблема обеспечения безопасности жизнедеятельности населения в условиях возможных или реальных чрезвычайных ситуаций. В данной работе предлагаются адекватные методы оценивания рисков жизнедеятельности с иелью их минимизации и ликвидации.

Ключевые слова: чрезвычайные ситуации; индивидуальный риск жизнедеятельности; коллективный риск жизнедеятельности; интегральный риск жизнедеятельности.

\section{THE APPROACH TO EVALUATING THE RISKS OF LIFE ACTIVITIES}

\author{
Mukola M. Bychenok (Doctor of Technical Sciences, Senior Research Fellow) \\ Oleksandr V. Voytko (Candidate of Military Sciences) \\ Volodymyr M. Cherneha (Candidate of Engineering Sciences)
}

National Defence University of Ukraine named after Ivan Cherniakhovsky, Kyiv, Ukraine 
The current state of technogenic and natural security of Ukraine is characterized by changes in the environment that are dangerous for life, caused primarily by the military conflict in the Donetsk and Lugansk regions, which are characterized by a significant number of heavy and mining enterprises, as well as by the influence of global climate change, irrational use of natural resources, river regulation network, the closure of numerous unprofitable mines by full or partially of flooding and more. Under these conditions, the risks of natural and man-made accidents and catastrophes, as well as human and material losses from them and unproductive costs of localization and liquidation of negative consequences, are constantly increasing. Therefore, the problem of ensuring the safety of vital activity of the population in the conditions of possible or real emergency situations acquires particular urgency. This paper proposes adequate methods for assessing the risks of vital activity in order to minimize and eliminate them.

Keywords: extraordinary situation; individual risk of life activity; collective risk of life activity; integral risk of life activity.

\section{References}

1. The Analytical review of the state of technogenic and natural safety in Ukraine in 2017. [Analitychnyj oghljad stanu tekhnoghennoji ta pryrodnoji bezpeky v Ukrajini za 2017 rik]. URL: http://www.dsns.gov.ua/files/2017/8/18/ Analit\%20dopovid/analit\%20oglad.pdf. 2. Dubel V. (2014). Features of eco-economic development of regions of Ukraine. [Osoblyvosti ekologho-ekonomichnogho rozvytku reghioniv Ukrajiny. Visnyk Donecjkogho nacionaljnogho universytetu. Serija V. Ekonomika i pravo]. №1. pp. 52-56. URL: $\quad$ http://jvestnik-c.donnu.edu.ua/article/view/382 3. Bychenok M., Roghozhyn O. (2003) [Do integhraljnoji ocinky socialjnykh ryzykiv vynyknennja nadzvychajnykh sytuacij] Ekologhija i resursy. Kyiv. IPNB. № 6. pp. 108124. 4. Bychenok M., Roghozhyn O., Jakovljev Je. (2004) [Pro ocinjuvannja ryzykiv zhyttjedijaljnosti i ghospodarjuvannja u pryrodno-tekhnoghennij sferi]. Ekologhija i resursy. Kyiv: IPNB. № 10. pp. 64-73. 5. Arsen Avakov (2018). Strategy of restoration of the integrity of Ukraine and de-occupation of the Donbass. "Small Steps Mechanism" [Strateghija deokupaciji Donbasu. "Mekhanizm malykh krokiv"]. URL: https://avakov.com/strategy-of-restoration-of-the-integrityof-ukraine-and-de-occupation-of-the-donbass-small-stepsmechanism.html. 6. Poberezhna L., Stanetsky A. (2017). Assessment of potential environmental risks from the antiterrorist operation [Ocinka potencijnykh ekologhichnykh ryzykiv vnaslidok provedennja antyterorystychnoji operaciji]. Naukovo-tekhnichnyj zhurnal "Tekhnoghennoekologhichna bezpeka". № 2. pp. 45-52. 7. Postanova KMU vid 26 veresnja 2018 roku №779 [Dejaki pytannja zapobighannja vynyknennju nadzvychajnykh sytuacij pryrodnogho ta tekhnoghennogho kharakteru]. 8. Alyimov V., Tarasova N. (2004). The technogenic risk. Analysis and evaluation. [Tehnogennyiy risk. Analiz i otsenka]. Studentbook. Moscow: IKTs "Akademkniga". p.188. 9. Ragozin A. (2003) The basic models and methods for assessing natural risks. [Osnovnyie modeli i metodyi otsenki prirodnyih riskov] Otsenka i upravlenie prirodnyimi riskami. Tematicheskiy tom. Moscow: Izdatelskaya firma
"KRUK". pp. 131-142. 10. Ivanjuta S. (2005) GIS realization of risk assessment of life from accidents on chemically dangerous objects. [GhIS realizacija ocinky ryzyku zhyttjedijaljnosti vid avarij na khimichno nebezpechnykh ob'jektakh]. Ekologhija i resursy. Kyiv: IPNB. № 11. pp. 95-101. 11. Ivanjuta S. (2015) [Rozrobka metodyky ocinky ryzyku zbytkiv vid nadzvychajnykh sytuacij $\mathrm{v}$ reghionakh Ukrajiny]. Vostochno-Evropeyskiy zhurnal peredovyih tehnologiy. Ekologiya. № 3/6 (75). pp. 48-53. 12. Yatsyuk O. (2015). Prediction consequences spout (release) of hazardous chemicals in case of accidents on chemically hazardous objects. [Proghnozuvannja naslidkiv vylyvu (vykydu) nebezpechnykh khimichnykh rechovyn u razi avarij na khimichno nebezpechnykh ob'jektakh]. URL: http://nd.nubip.edu.ua/2015 8/12.pdf.

13. The order of Ministry of Emergencies of Ukraine №73/82/64/122 from 27.03.2001 "On approval of the Methodology for predicting the consequences of the outflow (release) of hazardous chemicals in accidents at industrial facilities and transport" [Nakaz Ministerstva $\mathrm{z}$ pytanj nadzvychajnykh sytuacij ta u spravakh zakhystu naselennja vid naslidkiv Chornobyljsjkoji katastrofy, Ministerstva aghrarnoji polityky, Ministerstva ekonomiky, Ministerstva ekologhiji i pryrodnykh resursiv "Pro zatverdzhennja Metodyky proghnozuvannja naslidkiv vylyvu (vykydu) nebezpechnykh khimichnykh rechovyn pry avarijakh na promyslovykh ob'jektakh i transporti”. URL: http://zakon.rada.gov.ua/laws/show/z0326-01.

14. Bespalov V. (2008). Comparison of the methods of the Ministry of Defense and the Ministry for Emergencies to predict the consequences of an accident with a chemically hazardous substance. [Porivnjannja metodyk MO i MNS dlja proghnozuvannja naslidkiv avariji $\mathrm{z}$ khimichno nebezpechnoju rechovynoju]. Systemy pidtrymky pryjnjattja rishenj. Teorija i praktyka. №6. pp. 60-64. 15. National report on the state of technogenic and natural safety in Ukraine in 2006 (2007). [Nacionaljna dopovidj pro stan tekhnoghennoji ta pryrodnoji bezpeky v Ukrajini u 2006]. Kyiv: DP "Chornobylj'interinform”. 236 p. 